\title{
Juridical Analysis of Individual Loan Guaranteed by Land Rights Which Shifted to Authentic Sale and Purchase Deed (Case Study Of The Supreme Court Decision Number 1857 K / Pdt / 2016)
}

\author{
Cindy $^{1}$, O.K. Isnainul ${ }^{2}$, Tommy Leonard ${ }^{3}$, Elvira Fitriyani Pakpahan ${ }^{4}$, Kartina Pakpahan ${ }^{5}$ \\ \{cindysofiann@gmail.com\} \\ Universitas Prima Indonesia
}

\begin{abstract}
This study analyzes normative provisions of debts with land guarantee, legality of transferring debt collateral to object of sale and purchase using notary deed and fair legal considerations and certainty in the decisions discussed. The results conclude that normative provisions regarding debts and receivables with land guarantees are regulated in Mortgage Rights Law Number 4 of 1996 concerning Mortgage Rights. the transition of debt guarantee into object of sale and purchase in lending and borrowing relationship have no correlation, a sale and purchase occurs clearly and in cash as stated in Article 1458 of the Civil Code and if there is a transfer of collateral, the creditor must go through the stages of land guarantee execution according to the provisions of the Mortgage Rights Law. Legal consideration is supposed to consider the legal facts, regarding legal actions of loan and sales, like paying the remaining debts following interest and cancelling the sales agreement to provide a sense of justice and legal certainty.
\end{abstract}

Keywords: debts; sale and purchase; land

\section{Introduction}

The agreement of money debt-credit is sorted to type of loan agreement, this is regulated in Chapter Thirteen of the Code of Civil Law Third Book. In Article 1754 Civil Law Code mentioned, Loaning is an agreement where one party gives the other a specific number of consumable goods due to usage, with a term where the other party will have to return the same number of goods in the same kind and condition. It has generally been described in Article 1754 Civil Law Code about loaning act if implemented in daily life then the act can happen in banking scope and individual scope. Usually, loaning is formed based on trust. It can be between friends, neighbour, or siblings, depends on the harmony and relationship in between the loaning party and loaned party. But still there are things that should be noticed so no party would be in loss. In practice the debtor always gives guarantee in form of moving or non-moving object for creditor to provide loans. If debtor can't pay back the loan, the guarantee object will be sold by the creditor.

Case that is researched related to secured loan where individual creditor provide loan to individual debtor in form of an amount of money guaranteed with a land. Broadly speaking case happens when debtor and creditor agreed to make a Loan and Borrow Money relation, and that 
agreement is made in presence of a Notary. By the agreement of the parties a Debt Recognition Agreement is made, with a land certificate as a guarantee while on the land certificate, a separate agreement is made in the form of Sale and Purchase deed that hasn't occurred. When the debtor defaulted then creditor with the Sale and Purchased deed claimed that the Land is his house based on the Sale and Purchased Agreement and ask the debtor to soon empty the house then do the locking.

With that case, debtor feel wronged because the first intention according to the debtor is to make a Loan Agreement not a Sale and Purchase Agreement so that the problem supposed to be solved by resolving the loan, since debtor felt like never selling the land and the land is a guarantee with Sale and Purchase Binding to guarantee and to assure the creditor for giving a loan to the debtor. This case then continues to the court and has been decided on incarceration that it has permanent legal force on Supreme Court Ruling Number 1857 K/PDT/2016. As for the problem formulation in this legal research is: 1 . How is the duly normative provision regarding loan and guarantee of land rights? 2. How is the legality regarding loaning guarantee switching to sale and purchase object with a Notary Certificate? 3. How is the necessarily just legal consideration and legal certainty by the judge on Supreme Court Ruling Number 1857/K/PDT/2016 should be?

\section{Research Methods}

The research type that is used in this research is normative juridical research. Normatively legal research is a literary law research method or else a way used in research is by researching existing library material. The research characteristic used is analytical descriptive. The meaning of descriptive here is to know the overall and systematic overview about the rule used related with the main issue on normative provision regarding loan with guarantee of land rights and also legal legality transfer of land rights with notary deed meanwhile what analysed analytically here is to reveal facts in the case analysed in this research specifically legal facts in courts related with the research object namely loan agreement and the transfer of rights on the land by using notary deed i.e. sale and purchase deed inspected. Data used in this research is secondary data.

\section{Results and Discussion}

\section{Duly Normative Provisions Regarding Loan with Guarantee of Land Rights}

The definition of accounts payable is the same as the loan agreement. The definition of loan according to Civil Code Law Article 1754 namely Loaning is an agreement where one party gives the other a specific number of consumable goods due to usage, with a term where the other party will have to return the same number of goods in the same kind and condition. Meanwhile guarantee of land rights is a form of collateral for immovable objects. Provision for types and kinds of immovable objects is regulated in Code of Civil Law Article 506 to 508. The thing that differentiates moving and non-moving objects is in the term of delivery and imposition. Delivering immovable object needs a formal requirement that is legally recorded, while for movable object delivery is done in real.

In guaranteeing the payment of debt, immovable object such as land is in category of paying debt with special guarantee. According to Article 1 Chapter 1 The Mortgage Law Number 4 Year 1996, mortgage right is a land guarantee charged following other objects that is one with 
the land for debt payment and giving prioritized position to creditor against another creditor. Normative mechanism related with binding guarantee of land rights is by setting mortgage rights. Charging mortgage rights process is done by giving mortgage rights where debtor submits to bank a land rights certificate which will be charged a mortgage right then the second step is to register the mortgage right basically in form of Granting Mortgage Rights Certificate made before a Land Titles Registrar which is then registered to City Land Office at latest 7 (seven) working days after signing.

After that then the Mortgage Rights Certificate on the collateralized object along with land rights certificate. Overall, the mortgage right quality is:

1. Cannot be divided which means the mortgage right is overloading the whole object and every part of it.

2. Additional agreement which means additional or complementary agreement to the main agreement is mortgage right depends on loan agreement between debtor and creditor made as payment guarantee.

3. Impositioning mortgage rights object more than once.

4. Parate Execution if debtor breaching contract then the first mortgage holder has the right to sell the mortgage object on his own authority through general auction and taking the payment from the selling result.

\section{Legality Regarding Shifting of Loan Guarantee to Sale Object with Notary Certificate}

Reviewing legality side of shifting loan guarantee to sale object with notary deed then the main thing has to reviewed is a shifting loan guarantee and sale-purchase act. According to Sudikno Mertokusumo a concrete incident needs to be searched for the general and abstract law. Concrete incident has to be met with legal regulations. Concrete incident has to be connected with legal regulations so it can be included in the regulations. Otherwise, the legal regulation must be adjusted with the incident to be applied.

The act of shifting loan guarantee to sale object with notary certificate practically is a concrete incident. Nevertheless, this matter needs to be compared with the legal regulation to the act of shifting the loan into sale related if the act arise in the middle of the public is proper to be done specially to comprehending the legal legality. Reviewing sale will always be identical with the shifting issue. The shifting that is reviewed in this study is a shifting devoted to the object land.

Shifting rights of land is divided to 2 (two) type:

1. Shifting in this case Devolving the right of land or the property right of the right holder to other party because the right holder passed away or through inheritance. Boedi Harsono said that the meaning of shifting shows a devolving of property right to other party because the right holder passed away. Shifting Property Right because inheritance happens "legally", meaning with the passing right holder, then the heir gets the Property Right legally since he passed away.

2. Shifted in this case Shifting the right of land or Property from the right holder to other party because a legal act purposely done so that the other party got the right. The legal act can be selling, exchanging, granting, incoming to company capital, giving inheritance or auctioning. Shifting or moving rights here, the party shifting must have the right and authority to shift the right, while the accepting party has to be qualified as the accepting right party.

Shifting right of sales objected land happened since the sales and purchase deed is signed before an authorized Land Titles Registrar and price is paid by the buyer to the seller. Shifting right of sales objected land means transfer of control juridically and physically at once. 
Authorized Land Titles Registrar, property right to the land sold to the buyer, those points upheld by the decision of Supreme Court of the Republic of Indonesia in Teddy Sabur vs Adhikara Ganda Cs case with the verdict dated 14 April 1980 Number 992K/Sip/1979. Based on that case, it is concluded that shifting rights with sales and shifting loan guarantee has no correlation.

As for legality of shifting a land guarantee is regulated in Article 20 to Article 21 Mortgage Law namely run by way one, selling with own authority (parate execution) where it is the right for the mortgage right holder to sell the mortgage object on his own through general auction without court order when the debtor default. Selling rights with own authority is the right that is given by law for the right holder through Mortgage Law reads "If debtor is breaching contract, first mortgage holder has the right to sell mortgage object on his own through auction and taking the loan payment on the selling result. Secondly, can be based on executorial title by court order. Thirdly being done by seller under the mortgage holder as regulated in The Mortgage Law Article 20 chapter 2 and 3.

\section{Just and Legally Certain Consideration by the Judge on the Supreme Court Verdict Analysis Number 1857/K/PDT/2016}

Outline case disposition started when an initial SD and an initial ED agreed to have a loan relation by the deal SD lend money on amount one hundred and fifty million Rupiah then their deal is putted in a loan agreement and sales agreement on a house belong to ED. Then on the day after the loan is due ED is unable to pay the debt, SD then confiscated ED's house by locking and declared that the house has been shifted on the basis of the Sales Agreement. On that matter ED then sued SD on the argument and action against the law and deceive because the initial intention is loan and not sales. In the decision of Medan District Court Number 461/PDT.G/2012/PN Mdn, dated 14 March 2013 with the verdict rejecting the entire lawsuit by plaintiff ED and on appeal plaintiff ED's plea the verdict of the District Court has been reinforced by Medan District Court, with verdict Number 395*PDT/2013/PT Mdn dated 21 February 2014.

In the verdict by The Supreme Court Judge on cassation level state that judges of District Court and High Court is not wrong for applying the law because verdicts and legal considerations is true and proper by rejecting the entire lawsuit by plaintiff entirely, verdict which is in accordance with the court facts considerate fairly by Judex Facti that shows disputed object is own by SD first defendant purchased legally from plaintiff before Notary as second defendant, plaintiff can't successfully show his lawsuit that legal relationship between him and defendant is loan and the right shifting on the disputed object by ED (plaintiff) to SD (defendant 1) is loan and right shifting on disputed object by ED (plaintiff) to SD (defendant 1) is legally flawed because it is the verdict of Judex Facti in aquo case reasoned to be reinforced and by that rejecting appeal for cassation filed by ED.

Reviewing from the justice side by the court judge in cassation level whether it is right to give a justice sense then the facts coming to the court has to be noticed. Therefore when observing the beginning of the legal action ED (debtor) and SD (creditor) did it was the legal action based on the principle of contract freedom seen from the two parties agreed to have loan where ED (debtor) needs money and lending from SD (creditor) amounting to Rp.150.000.000 (a hundred and fifty million Rupiah), and as the guarantee ED (debtor) then submit a land certificate to SD (kreditur) to hold by making a Sale and Purchased deed before a Notary. The two parties deed from the justice side indeed ED (debtor) as a lender must return the money lended as well it is something fair for SD (creditor) when ED (debtor) gives his land certificate to $\mathrm{SD}$ (creditor). 
If we look at the judge's consideration in this case, it doesn't considerate the two parties' case from the procedure side and loan mechanism and sales agreement but the judge considerate the object that is disputed namely a land/house SD (creditor) got from ED (debtor). In the court fact outlined by ED (debtor) has tried to offer the house to other party to pay his debt to SD (creditor) and almost bought by the other party amounting Rp.250.000.000 (two hundred and fifty million Rupiah) and from the selling outcome the remaining debt by ED (debtor) to SD (creditor) will be paid, but SD (creditor) quite oppositely disagrees with the seller.

The judge in this case supposedly have to consider the matter that this is a loan where initially ED (debtor) loaned to SD (creditor) in amount of Rp150.000.000 (one hundred and fifty million Rupiah), if the house is sold by ED (debtor) by a good behaviour from other party wanting to buy the house to cover up the debt supposedly is right and can be accepted logically, but oppositely SD (creditor) disagree to the seller and precisely only giving compensation amounting Rp.10.000.000 (ten million Rupiah) and immediately asks ED (debtor) to empty the house.

This act should be less precise because the house is sold to other party amounting Rp.250.000.000 (two hundred and fifty million Rupiah) then it covers up debt from ED (debtor) to SD amounting Rp.150.000.000 (one hundred and fifty million Rupiah), ED (debtor) can still enjoy the selling result in amount of Rp.100.000.000 (one hundred million Rupiah) but this is instead not happening. Therefore, justice here is created for SD (creditor) by having and dominating land based on sales certificate, but it becomes unfair for ED (debtor) because procedurally the desire of land sales is done because the loan deed.

Meanwhile from the legal certainty, there are four matters related to the legal certainty meaning one of which is, law is based on the fact (tatsachen), not an assessment formulation which will be done by judge like goodwill or courtesy. As been known that legal certainty of two parties deed namely loan and sales, basically has been referring to Code of Civil Law about the legal terms of the agreement and in its form if done in form of authentic deed before Notary certainly from legality and legal certainty side are guaranteed, but if we notice the deed of ED (debtor) and SD (creditor) who made 2(two) legal deed namely loan and sales are indeed allowed by referring to freedom of contract principle, but action by ED (debtor) and SD (creditor) is an action that refers to smuggling law potential which is instead disadvantaged them, because between loan and sales as described in previous sub is a different deed and cannot be put together, but can still happen as ED (debtor) and SD (creditor) wish.

In the lawsuit by ED (debtor) as appeal applicant that include consideration of a jurisprudence, in Supreme Court of Republic of Indonesia verdict jurisprudence Number 3438 K/Pdt/1985 dated 9 December 1987 such as "a loan agreement guaranteed with a land cannot just become a legal land sales action, where the debtor do not pay it, this thing is supposed right" Judge should be considering the jurisprudence in making his decision, but instead the judge doesn't consider that matter, the judge rule out it instead, basically judge can rule out that jurisprudence indeed.

Loan and sales action supposed to be decided by the judge wisely to create a law certainty, where loan is solved by loan and sales should have been cancelled. By taking an example of other civil case comparison namely a case started by a defendant as a debtor has lent money to a plaintiff an amount of Rp.15.000.000 (fifteen million Rupiah) with 2 years of period time guaranteed by a building to the creditor, until the debtor cannot pay, in the lawsuit creditor request the judge to declare that the land along with building upside it is a guarantee to pay defendant's debt. Until the high court judge's verdict in his consideration declared that "the dispute between defendant and plaintiff is not about ownership or property right claim, so that insurance object cannot be owned, this is against the legal order." 
Based on the case comparison above judge's verdict in ED (debtor) and SD (creditor) case from legal certainty side is less able to create a legal certainty to the two parties, because judge basically doesn't considerate the 2 (two) legal actions related one another namely land sales and loan. ED (debtor) as a debtor has denied that the sales certificate signing is based to ED (debtor) owed SD (creditor) money amounting Rp. 150.000.000 (one hundred and fifty million Rupiah) at that time so that SD (creditor) is convinced to give loan.

Supposedly judge have to dig for information more about this, judge is also supposed to ask Notary in charge to give information directly because at the same time the loan and sales agreement are made before the notary in charge, so the notary know the real initial intention and the purpose is loan and not sales and judge also supposed to consider earlier jurisprudence that has similar case with this case, so as judge can scrutinize this action and take a judgment that can create a legal certainty for all parties.

\section{Conclusion}

The conclusion to the above study: first, normative provisions regarding rules and loan implementation generally ruled in several article in the Code of Civil Law one of which is the person accepting loan is becoming an absolute owner to the object loaned, and if the object vanishes, in any way the loss becomes the dependents of the lender as ruled in the Civil Law Code Article 1755 object lent become the responsibility of the lender. Practically loan of a creditor both individual or legal entities as a lender is always asking for a guarantee. The most common guarantee is a land property right where the normative provision of binding land property right is ruled in a special law namely Mortgage Law Number 4 Year 1996 about Mortgage, where mortgage law is a guarantee of charged land including other things that is one with the land for debt payment and giving prioritized position to certain creditor to other creditors.

Second, legality of the shifting loan guarantee to become a sales object is not right because there is no correlation or relation to one another, shifting loan guarantee happens by referring to a legal rule specialize about the guarantee, one of which is to immovable object then has to refer to the Mortgage Law, shifting loan guarantee happens if the debtor defaults, and when defaulting shifting guarantee to creditor also will go through the steps of executing the immovable object guaranteed according to the law ruling it, meanwhile to the sales object ruled om the Civil Law Code Article 1458 ruling sales is done fairly and in cash. The sales implementation ought to be done at that time and can be done before a Notary and a Land Titles Registrar, so that between guaranteed object becoming sales object got no relation at all and so it can't be done.

Third, legal consideration from the justice and legal certainty side by court judge at the cassation level supposed to considerate the legal facts about 2 (two) legal act loan with a land/house guaranteed becoming sales that supposed to be prohibited and is against the legal rule so that based on the legal fact judge supposed to give consideration from both justice and legal certainty side where the loan dispute resolution is first clarified by asking the owing party (debtor) pay the debt following the interest and the lending party (creditor) accepting the remaining payment following the interest. By not consideration the legal loan facts and directly referring to the sales action justified by the judge where creditor as the buyer indeed less giving legal justice and certainty to all parties especially the debtor. 


\section{References}

[1] Achmad Ali, 2012. Menguak Teori Hukum (Legal Theory) dan Teori Peradilan (Judicialprudence), termasuk interperetasi Undang undang (Legisprudence), Jakarta: Kencana.

[2] Gatot Supramono, 2013. Perjanjian Utang Piutang, Jakarta: Kencana.

[3] Mien R. Uno, 2005. Sukses Membawa Diri Di Segala Kesempatan, Jakarta: Gramedia Pustaka Utama.

[4] Ralona M, 2006. Kamus Istilah Populer Ekonomi, Jakarta: Gorga media.

[5] Sahat HMT Sinaga, 2007. Jual Beli Tanah Dan Pencatatan Peralihan Hak, Bandung: Pustaka Sutra.

[6] Urip Santoso, Jual Beli Tanah Hak Milik Yang Bertanda Bukti Petuk Pajak Bumi (Kutipan Letter C), Fakultas Hiukum Universitas Airlangga Surabaya Jurnal Perspektif Volume XVII Nomor 2 Tahun 2012 Edisi Mei.

[7] Sovia Hasanah, Ulasan lengkap: Perbedaan Das Sollen dengan Das Sein, diakses melaluihttps://www.hukumonline.com/klinik/detail/lt5acd738a592ef/perbedaan-das-sollen-dengandas-sein/ pada tanggal 12 Juni 2020

[8] putusan Nomor 566/PDT/2015/PT. DKI tanggal 1 Februari 2016 diakses melalui https://www.hukum-hukum.com/2018/11/hutang-piutang-tidak-dapat-dicampur-aduk-kepemilikanagunan.html pada tanggal 26 Juli 2020. 